\title{
Theoretical Research on the Principle of Equality in Civil Law from the Perspective of Civil Society
}

\author{
Ruyuan Guo ${ }^{1}$ \\ ${ }^{1}$ Law School of Beijing Normal University, Beijing, China \\ Correspondence: Ruyuan Guo, Law School of Beijing Normal University, No. 19, XinJieKouWai St. HaiDian \\ District, Beijing 100875, P. R. China. E-mail:1065710943@qq.com
}

Received: August 29, 2019

Accepted: September 15, 2019

Online Published: September 29, 2019

doi:10.5539/ass.v15n10p141

URL: https://doi.org/10.5539/ass.v15n10p141

\begin{abstract}
The assertion of equality of rights and abilities in the equality principle of civil law is incompatible with social practice. This kind of realistic contradiction forces the study of the essence of the equality principle of civil law to change a new path from "what is the principle of equality of civil law" to "what is not". Based on this, the "essence" of the equality principle of civil law is to highlight the "principle" attribute of "equality" by excluding regularity assertion, and guarantee the qualification equality of social subjects in the field of private law by expanding rather than limiting the boundaries of interpretation space. The "essential" argument of the equality principle of civil law makes the interpretation of negative and positive implications logically possible. Civil law is based on the principle of equality. The negative implication of the equality principle derives the principle of freedom. The positive implication gives rise to the principle of honesty and credit and the principle of fairness and justice, which are the guarantees of the principle of freedom. Civil law establishes communication with the times through the dynamic and synchronic nature of the binary meaning of the equality principle, and equalizes the governance of civil law through the negative and positive implications of "one goes up and the other goes down".
\end{abstract}

Keywords: the equality principle of civil law, essence, positive implication, negative implication

The word "equality" is originally a buddhist term. Buddhism holds that the essence of the universe is integrated. There is no difference between all laws and all living beings, so it is called equality. (Note 1) Later, it often refers to people having the same status and treatment in social, political, economic, legal and other aspects. Zunxian Huang of the Qing Dynasty wrote a poem in the chronicle: "all red, yellow, white and black seeds are treated as equals." (Note 2) The judgment of "equality" often depends on objective evaluation criteria. For example, no matter how much social subjects reject the compulsory nature of education or how eager they are to accept more education, no matter how subjective social subjects are about the number of days of holidays, different social subjects can be considered to be treated equally as long as they receive compulsory education and enjoy legal holidays. However, "principle" is an abstract value concept, which runs through the whole thing and drives and guides the basic development direction of things with its unique value connotation. The combination of "equality" and "principle" makes "equality" tend to "concept", and "principle" shows unique value connotation because of "equality".

\section{Presentation of Problem}

However, it is far from enough to understand the equality principle in civil law by the interpretation of meaning. Chinese scholars of civil law have many books and papers about this issue. In general, one is "essence theory". Professor Liming Wang maintains that "the principle of equality is mainly embodied in the equality of the rights and abilities of civil subjects, that is, the abstract equality of personality." (Wang, 2008, p. 31) Professor Yi Wang believes that "the principle of equality is mainly embodied in the equality of the civil rights capacities of civil subjects, that is, the abstract personality equality of civil subjects as' human 'in civil law". (Wang, 2013, p. 93) This view is reflected in "Lu'an Innovation Small Loan Co., Ltd. v. Lu'an Zhengtai Material Supply Co., Ltd. and Other Private Lending Disputes". The court held that "according to the principles of equality, fairness and good faith in the civil law, the rights of both parties should be treated fairly and protected equally by the people's court." (Note 3) The other is "implication theory". The theoretical emphasis on "implication theory" can be divided into four categories. The first category is inclined to the equality principle of "weak form". Professor Yi 
Wang believes that "the equality principle of modern civil law emphasizes equal treatment in the sense of strong form while giving more attention to equal treatment in the sense of weakness". (Wang, 2013, p. 93) The second category tends to be the "strong" equality principle. According to professor Xianzhong Sun, "equality in civil law is equality of status and opportunity, not equality or equality of results. Civil law only provides a platform for the parties to carry out equal activities, but cannot make mandatory requirements on whether the results of activities are equivalent or equal. In fact, the equivalent compensation may not meet the wishes of the parties." (Sun, 2004, p. 48) The third category tends to analogize the "equality" of the constitution with the equality principle of civil law. Professor Wanlin Peng believes that "the principle of equality in China's civil law is the concrete embodiment of the principle that citizens are equal before the law in the constitution." (Peng, 2007, p. 41) The fourth category evaluates the equality principle of civil law from the perspective of legal operation. Professor Maorong Huang believes that "the principle of equality is a legal principle derived from the concept of law and recognized by current law. The concept of law is the expression of human's will to pursue the supreme good, which is limited by human's specific cultural level in time and space. The principle of equality is reflected in 'the same case should be handled the same way'." (Huang, 2018, p. 9, 11, 12.)

The "implication theory" and "essence theory" of the principle of equality in civil law are essentially two different levels of problems. "Essence theory" discusses more from the substantive level of the principle of equality in civil law, that is, the question of "what is the principle of equality in civil law." The "implication theory" focuses on the value embodiment of the equality principle of civil law, specifically the question of "what to do". It is known that the "essence" of the principle of equality in civil law will determine its "implication".

\section{Analysis of "Essence" of Equality Principle of Civil Law}

\subsection{Analysis on the Theory of "Essence" of Equality Principle in Civil Law}

The assertion of equality of rights and abilities in the equality principle of civil law is incompatible with social practice. The principle of equality in civil law should be universally applicable principle. This universality is reflected in not distinguishing the age and occupation of the subject. If the right ability can be limited by means of interpretation, then the right ability cannot be regarded as the equal principle of civil law. If not, it will only damage the spirit of the principle of equality. It is well known that the rights of civil subjects can vary among individuals due to age, mental status, occupation and other reasons. In addition, the administrative subject will also restrict the civil capacity of the social subject to some extent, which also exists in rural people, urban people and different urban people, in order to realize the reasonable allocation of resources in nature, space, medical care and education. "Notice on Strengthening Land Transfer Management and Prohibition of Speculation of Land Sale" (Published by Office [1999] no. 39) stipulated that 'farmers' collective land use rights shall not be sold, transferred or rented for non-agricultural construction... Peasants' houses may not be sold to city dwellers... ." (Xu, 2015, p. 23, 24) Theoretically, the purchasing ability between the subjects who meet the requirement of certain civil capacity should be equal. In fact, the purchasing ability of civil subjects in different regions varies according to the different household registration policies, because the qualification of civil subjects to purchase houses is directly related to the household registration. Take Beijing and Zhengzhou as examples: article 12 of the notice of "rules for the administration of the operation and management of integral household registration in Beijing (trial)" (no. [2018] 64), "interpretation of qualification conditions (1) holding this municipality's residence permit... (2) not exceeding the statutory retirement age... (3) pay social insurance for 7 years or more in Beijing. (4) no criminal record... ." Article 13 also sets out detailed requirements for "lawful stable employment index", "lawful stable residence index", "educational background index", "occupation and residence area index", "innovation and entrepreneurship index", "tax payment index" and "age index". In contrast, the " Notice of the General Office of the People's Government of Zhengzhou Municipality on Printing and Distributing the Implementation Measures for the Settlement of Talents in Zhengzhou City (Provisional) " ([2017] No. 127), Article 2, "These measures apply to graduates of secondary vocational school or above, graduates of vocational (technical) colleges and universities, returned students from overseas study and functional talents who have voluntarily settled in urban areas within the administrative region of Zhengzhou. " Article 3 and Article 4 provide for specific materials to be submitted. Therefore, it is a misunderstanding to equate the equality principle of civil law with the equality of rights and abilities.

Law is different from natural science, the connotation of each concept is more of a convention, not as rigorous as the nature of the tenuous. Brian Bix presents four options for conceptual propositions: 1) they are arbitrary, 2) they use language, 3) they try to explain what the "important" or "interesting" aspects of some problems are and 4) they establish an evaluation standard to test the label. (Brian, 2008, p. 34) The current concept of the principle of equality in civil law obviously conforms to the first three choices, and the definition standard of "what is" roughly excludes the "evaluation standard" that should be set but not. The model of "what is" may have many 
disadvantages, such as one-sidedness, when considering the possible implication space of the principle of equality in civil law. Therefore, we might as well change the way of thinking to define the essence of the equality principle in civil law and adopt the definition mode of "what is not" of the equality principle in civil law. Scientific definition has its positive significance and can reduce subjectivity, although it is difficult to get rid of subjectivity and semantic diversity.

\subsection{The Thoughts of Defining "Essence" of Equality Principle in Civil Law}

The dilemma of defining the essence of the equality principle in civil law forces the research thinking to shift from "what is" to "what is not". Correspondingly, the research object should also move from the principle itself to the field of legal rules, looking at principles from the perspective of legal rules, we can not only grasp the legal principles comprehensively, but also remove the non-principled attributes from the essential field of equality principle by analogy.

The law's advantages are also its limitations. The law always uses the clearest word concept (clear) to logically fix the behavior and consequences in a causal relationship (affirmative) and is universally applicable to uncertain, unspecified objects (universal). The non-specific social subjects guide their individual actions through the relatively clear legal projections. If we look at law dialectically, we will find that the characteristics of law are the limits of law. Generality and individuality, universality and particularity are unified in the whole process of things and their development. The universality of law will inevitably appear to be stretched when faced with complicated society; The law is composed of spoken and written language and specific normative sentences, although the legislator recognizes that vague language will affect the accurate application of the law and tries his best to adopt precise and definite words to construct the law. However, under the specific social background, the existence of multicultural value and the difference of professional cultivation between legislator and legal audience make the vagueness of law inevitable. In addition, the clarity of the law is challenged by changing and rapidly developing society, so it shows hysteresis. (Xu, 2004, pp. 180-187) Today, the "supplementary" power of judges is gradually endowed, because legislators gradually realize their own limitations, the lag of the code is also clearly recognized. The "Swiss civil code" is a typical proof. At the same time, in addition to clear legal rules, vague and flexible legal principles are gradually reflected in the code, which makes the code full of vitality and provides a channel for the moderate intervention of judges. Therefore, the civil law and even any law are almost the unity of certainty and uncertainty, accuracy and fuzziness, Certainty and accuracy are mainly concentrated in the norms of civil law, while uncertainty and fuzziness are mainly concentrated in the principles of civil law. (Xu, 2004, p. 23)

Briefly, the legal rules and legal principles are summarized. The former has the micro guidance, maneuverability, certainty and predictability. The latter is the comprehensive and stable principle and criterion of the basis or origin of legal rules, which has the function of wide coverage, macro-guidance and strong stability. (Zhang, 1989, p. $27,28,29)$ On the contrary, the principle of civil law aims to preserve the vitality of the era with a code, guarantee the "law" to be followed, and make up for the deficiency of legal norms. The principles of civil law can always abstract the spirit of civil law to avoid "transgression" of the rule of law activities under the guidance of the principles of civil law. Therefore, from the perspective of the evolution of legal principles, the irregularity of the adjustment scope of norms creates opportunities for the application of principles, and it is the premise and guarantee of the application of principles to abstract the spirit of civil law. However, from the point of view of the logic of the application of the principles of civil law, the principle of civil law embodies the spirit and temperament of private law is the premise of the application of the principles of civil law. The second is the civil legislation, civil activities and judicial interpretation according to the principles of civil law. (Wang, 2013, p. 92) Finally, there is the possibility of filling loopholes in the specification.

\subsection{The "Essence" of Equality Principle in Civil Law}

The theory that the principle of equality in civil law is the capacity of equal rights blindly caters to the definite value of legal rules and neglects and greatly limits the spiritual connotation of the principle of equality in civil law. The value of the principle of equality in civil law is greatly suppressed in practice. The definition of the "essence" of the principle of equality in civil law should highlight the attribute of the principle. Only in this way can the interpretation space of the principle of equality in civil law be guaranteed.

\section{Analysis of the "Implication" of Equality Principle in Civil Law}

From the perspective of legal rank, civil law is made according to the constitution and belongs to the basic law. The constitution and civil law are also known as the "mother law". However, the "mother" of the constitution is reflected in its supreme position, while the "mother" of the civil law is reflected in the "age". Historically, the concept of freedom and equality in modern society originated from the civil law rather than the constitution, and 
the civil law can provide ideological nutrients for the development of the constitution. The basic principles of civil law are not so much derived from the constitution as they achieve the "docking" of historical spiritual ideas. (Ma, 2005, pp. 3-9)

\subsection{The Purport of the Principle of Equality in Civil Law}

"The Declaration of Independence" proclaimed that "all men are created equal". "Declaration of the Rights of Man and of the Citizen" ("Déclaration des Droits del' Homme et du Citoyen") proclaimed that "all men are born and remain free, equal in rights". Since the 18th century, the right movement has lost its deities, and the protection of gods' will and heaven's way is no longer the focus, and its ultimate goal has turned to the protection of life and rights. (Long, 2014, p. 158) As social individuals, people have the natural attribute of universal pursuit of freedom, and hope to be effectively guaranteed by certain "authority". The propositions of "Du Contrat Social" and other theories are theoretically demonstrated to guarantee the freedom of social individuals. In the game of state power and individual rights, freedom and equality are particularly important. And the true realization of freedom needs to be maintained by equality. If equality is divided into equality of opportunity and equality of outcome, the need for equality of opportunity appears more urgent at first. In Marx's view, people are social, and they are always connected with each other through social practice, which means they depend on each other more. Regarding equality from a development perspective, although equality of opportunity has brought about freedom, it cannot be excluded that people have different family circumstances, endowments, knowledge, temperament, opportunities, energy and experience. So, when facing the same equality of opportunity, different people obtain or even monopolize the limited resources of the society due to individual differences. The "Matthew Effect" exacerbates the monopoly effect and thus leads to the inequality between people due to material possessions. Such inequality will make the dependence between people manifest as attachment or subordination. Material inequality will gradually evolve into psychological and identity inequality. At this point, the importance of equality of results comes to the fore. According to the civil law, economic law and administrative law enacted by the constitution, the society will make certain adjustments to achieve equality and strive to achieve a balance between opportunity and equality of results. If equality of opportunity is the meaning of freedom, equality of results is the guarantee of freedom. (Zheng, 2007, p. 156) Therefore, the constitution not only pursues equality in form, but also hopes to achieve equality in substance by means of balanced social development. The spirit and goals of the constitution are manifested and realized by the laws enacted in accordance with the constitution. Civil law, as the basic law regulating the personal and property relations among equal subjects, the universal applicability of civil law makes it possible for the spirit of equality in the constitution to be widely spread. However, the principle of equality in civil law reflects the strong characteristics of private law.

In the field of private rights, civil law always appears in a passive identity, which is reflected in that she does not object to the gap between the rich and the poor and the polarization of property. Every private subject is favored by the mother (civil law) like a child. The property of private rights in the civil law makes her protect the wealth acquired by private subjects through legal means. She does not interfere with the behavior of private subjects to grab wealth without violating the legal provisions and the moral bottom line of "public order and good custom" passively, showing great preference to those who obey the discipline. This passivity of the civil law doomed her to be incapable of constitutional equality. Using the thinking mode of equality principle in constitution and economic law to examine the principle of equality in civil law is bound to misunderstand the principle of equality in civil law. The equality principle of civil law is more reflected in the passive meaning of equality. Every social subject can actively enjoy the opportunity equality in the civil law meaning, which is promoted by the passive meaning of civil law. This passivity is reflected not only in the property field, but also in the personal field. The court pointed out that "from the principle of fairness and equality in the civil law, illegitimate children and illegitimate children have equal rights to education and upbringing" in the case of "liu mou v. liu hongmin affirming parent-child relationship dispute". (Note 4) From the opinions of the court, we can find out that the legal status of illegitimate children and illegitimate children has been regarded as equal by the civil law. The civil law always shows passivity when the spirit of this principle is not broken. However, the civil law will actively intervene to punish the private subject when the private subject breaks the rules. Therefore, the civil law abhors the private subject who does not abide by the rules of the "game" and achieve their own goals through "cheat". In this sense, "inequality" in civil law can be interpreted as those behaviors that violate the established rules of civil law. In order to make up for the damage caused by the "unequal" behaviors of private subjects, civil law usually shows rare harsh. The civil law will examine the subjective and objective state of private subjects when they carry out "unequal" acts, and accordingly compensate the private subjects who suffer damage and punish the infringers. At this time, the positive attribute of the equality principle of civil law shows the "public law" 
temperament that is rare in private law, even if it seems to be a little "overcorrecting" in the outside world. For example, the court held that "postal kiosk agricultural and industrial joint enterprise and dazu county postal kiosk shipping co., Itd. have administrative relations and do not have the qualification of labor dispatch. The labor dispatch contract which concluded according to the administrative act violates the principle of equality of the civil law is invalid " in "Dazu County Postal Booth Shipping Co., LTD. v. Ye Zhaoxiang Labor Dispute Case". (Note 5)

\subsection{The "Implication" of Equality Principle in Civil Law}

\subsubsection{The Negative Implications of the Principle of Equality in Civil Law}

On the macro level, the passive attribute of equality principle of civil law embodies the abstract value concept of equality and reflects the spirit of private law. Just as the lighthouse of the night sea indicates the direction of private subject, just as the engine of the giant wheel provides power for private subject to move forward. Before the Economic Reform and open up, China gradually formed a unified pattern of state-owned economy with large state-owned enterprises as the core content and dominant position. (Luo, 2009, p. 20) Since the Economic Reform and open up, the management and operation mode of state-owned enterprises was difficult to adapt to the law of market economy. A series of measures were implemented, such as "the conversion management mechanism of the separation of two rights", "the establishment and improvement of enterprise property rights system", "the improvement of corporate governance structure", "the reform of state-owned assets management system" and "the implementation of the reform of non-tradable shares", in order to realize the state-owned enterprise with the integration of market economy, to shape the state-owned enterprises as the main body of the market. (Ren, 2016, p. 77, 78, 79) At the same time, the dominant position of individual and private economy in the market has been gradually established, and the market vitality has been continuously strengthened. The individual's concept of the development of the market economy has also gradually gone through the cognitive stage of "rejection", "hesitation" and "acceptance". To sum up, China's economic system reflects three problems in the process of reform and development. First, the development concept of market economy urgently needs to be deeply rooted. Second, state-owned enterprises need to adapt their management and operation to the development law of market economy. Third, individual private enterprises need to be given a high degree of market identity, to ensure that the individual private entities, private entities and state-owned enterprises can enjoy "equal" competition opportunities. (Xu, 2004, p. 50) The negative attribute of the principle of equality in civil law conforms to the special needs of China's special historical development in a particular period, and alleviates and even solves these three problems to some extent. First, in terms of concept, the passive attribute of equality principle of civil law derives the concept of equal development of social subjects, which updates people's old concepts and frees people from identity relations. (Peng, 2007, p. 42) Second, in terms of market subjects, the passive attribute of equality principle of civil law guarantees equal development opportunities for social subjects. "Equality" is the pressure and spur for state-owned enterprises, while "equality" is the guarantee, opportunity and incentive for private subjects. Therefore, at the beginning of the development of market economy in China, the passive attribute of equality principle in civil law is particularly important and necessary.

\subsubsection{The Positive Implications of the Principle of Equality in Civil Law}

The positive attribute of the principle of equality in civil law aims to regulate the behavior of social subjects and ensure the equality of the legal status of private subjects in a substantial sense. It can be divided into three aspects. One is to control the voluntary behavior of the actor from the perspective of legal effect. The second is to fill the incomplete legal consequences caused by the legal factual act; The third is to deny the right ability of the actor with special status in a specific field.

The principle of equality in civil law controls the voluntary act of the doer from the perspective of legal effect. For example, article 146 of the "general provisions of civil law" makes a negative evaluation on the effectiveness of the civil legal act of "false expression and concealment". Article 153 of the "general provisions of civil law" makes a negative evaluation on the effectiveness of civil legal acts that "violation of mandatory provisions and public order and good customs ". Article 154 of the "general provisions of civil law" makes a negative evaluation on the effectiveness of the civil legal act of "malicious collusion". In response to civil legal acts committed in the form of "material misunderstanding", "fraudulent means", "third party fraud", "coercive means" and "obviously unfair", Articles 147, 148, 149 and 151 of the "general provisions of civil law" give revocable legal evaluation respectively. The "general provisions of civil law" aims to alert private subjects who wants to break through the negative attribute boundary of equality principle of civil law and restore the adverse legal consequences to the initial state of equality as far as possible. For example, the court held that "according to the principle of equality in the civil law, when the rights and interests of civil subjects are infringed, they should follow the principles of 
fairness and equality in the civil law to protect them" in the "Civil Judgment of The Second Instance of Liability Dispute Over Motor Vehicle Accident between Unit 91257 of the People's Liberation Army and Hou Liangkuan". (Note 6)

The principle of equality in civil law fills the incomplete legal consequences. The Chinese Civil Code has learned the German Civil Code to a great extent in legislative technology, which abstracts common rules from identity law and property law as the general rule. The market economy makes the economic model and legal relationship show diversified evolution. As a result, the connotation of the general norms of civil law is enriched. The positive meaning scope of the principle of equality in civil law is also broadened. The connotation of property and other legal norms of civil law is directly influenced by the positive meaning of the principle of equality in civil law. Moreover, the civil law will show this influence through specific norms. According to the relevant provisions of the "property law", the real right holder is entitled to request the elimination of the obstruction or the elimination of the danger. Where the realty or chattel is damaged, the right holder may request for repair, rework, replacement or restoration of the original condition. The positive attribute of the principle of equality in civil law ensures the perfect state of real right. In addition, according to the relevant provisions of the "contract law", the factual behavior that violates the moral standards will be negatively evaluated due to the positive role of the equality principle in the civil law. This spirit has also been embodied in judicial practice. For example, The court held that, "the fine for late payment belongs to the scope of administrative management, and there is no legal evidence to stipulate the fine for late payment in the civil contract, and the party who violates the principle of equality and fairness of the civil law with the high fine for late payment is severely punished, so the court will not support it" in "Dispute Case of Shaanxi Lanxiang Material Trade co., LTD. v. Shaanxi Small Spot Automobile Service Management Co., LTD." (Note 7)

The principle of equality in civil law negates the right ability of special identity actor in specific field. In general, we believe that the purpose of "property law" and "contract law" is to fill the damage and restore the rights of the right holders to a satisfactory state. In contrast, "company act" is so severe to the directors and senior managers who is offending that their certain rights will be deprived. Civil law will be pleased with companies that have made a lot of money through fair competition. Companies are the basic elements of the market, and dominated by senior management. Companies occupy a certain amount of social wealth and resources. In a sense, the success or failure of a company is related to the interests of the members of the company and the prosperity and stability of the market. According to article 146 of the "company act", it can be seen that for the company's managers who violates the law and discipline, the punishment is "Where do you fall and never get up". It can be seen the proper meaning of the equality principle of the civil law from the article 146 of the "company act". This idea has been reflected in "Huai'an Henglong Real Estate Development Co., LTD. v. Zhang Jinyuan Company Interest Liability Dispute Case". (Note 8)

\section{Conclusions}

The essence of the principle of equality in civil law makes the dual interpretation of its meaning possible logically. Civil law establishes communication with the times through the dynamic and synchronic nature of the binary meaning of the equality principle. Under the influence of different time and space, the principle of equality in civil law always influences legislation and judicature with different meanings of "positive" and "negative". Different periods and stages of national governance, social development and the improvement of market mechanism all put forward new requirements for civil law. These requirements are not immediately reflected in the civil code norms, but are immediately gotten by the equality principle of the civil law. Vigilant judiciaries and wise legal interpreters are able to express this delicate value proposition in almost the right way. The principle of equality in civil law is precisely through the dynamic "passive" and "positive" attributes to balance the times of the rule of law.

It is generally believed that in addition to the principle of equality, the basic principles of civil law include the principle of freedom, the principle of fairness and the principle of good faith. However, the meaning of the equality principle not only makes it dominant, but also makes it the source of other principles. Both the passive attribute and the positive attribute of the principle of equality in civil law have flexible interpretation space for each other and establish a relatively clear scope of private subject activities through the rules of civil law. The civil law allows the freedom of behavior of the private subject with a passive attitude, but this behavior should be based on the principle of equality. The principle of equality in civil law makes the moderate freedom of private subject possible, which is the theoretical basis for the existence of the principle of freedom. The freedom between private subjects is often expressed in the form of will autonomy, which makes the isolated private subjects have economic and legal relations with each other. In the eyes of legal economists, every socioeconomic person faced with the "prisoner's dilemma" is influenced by the invisible hand of self-interest, which often keeps 
them away from common well-being rather than from getting it. (Brian, 2008, p. 246, 247) This unsatisfactory result can be attributed to the asymmetric information between social subjects and the lack of full freedom of interest game. In the case of free and true expression of will, the social subject seems to be closer to the "Pareto efficiency" of both sides. Therefore, the autonomy of social subjects realizes the maximization of interests between each other during the process of social subjects pursuing interests. At the same time, the subjects who enjoy freedom pursue their interests in a more pluralistic way. During this period, more personal and property relations models will be derived. These legal relationships need to be adjusted by civil law. For those legal relations that have not yet been specifically stipulated by civil law norms, they first stimulate the realization of a new balance between "passive" and "negative" of the principle of equality, and then reflect them in judicial and legislative practice. Therefore, the principle of equality in civil law promotes the principle of freedom in civil law, and the principle of freedom in civil law constantly influences the principle of equality in civil law.

Although the civil law tolerates the freedom of the private subject, the enthusiasm of the civil law will be stimulated when the private subject surpasses the established rules of the civil law. The equal relationship between private subjects is based on the observance of morality and rules. The private subjects who "non-compliance" the rule are dishonest and unfair, and their freedom will be restricted to a certain extent. Such as the "validity flaw" of the ideographic act, the "result filling" of the factual act, the "punishment of the loss of power" of the person with specific identity, and so on. Therefore, the positive attribute of the principle of equality in civil law is the basis and source of the principle of good faith and the principle of fairness and justice.

On the whole, the principle of Equality in Civil Law is the basis of the principle of civil law. The passive connotation of the principle of equality in civil law gives rise to the principle of freedom, which is also pursued by civil law. The principle of freedom and the principle of equality influence each other. The positive connotation of the principle of equality in civil law gives rise to the principle of good faith and the principle of fairness and justice, both of which are the protection of the principle of freedom.

\section{References}

Brian, B. (2008). Jurisprudence: Theory and Context. Beijing: Law Press.

Huang, M. R. (2018). On Jurisprudence in Civil Law. Heilongiang: The North of Law.

Long, Q. L. (2014). The Rule of Law and Regulation - Using Foucault Theory to Analyze the Modernization of Law. Guangzhou: Journal of ZhongShan University (social science edition).

Luo, Z. Z. (2009). The Historical Track of New China Enterprise Scale Evolution. Heilongjiang: Learning and Exploration.

Ma, L. (2005). Discussion on the Relationship between Constitution and Ministry Law. Shanghai: Law.

Peng, W. L. (2007). The Civil Law. Beijing: China University of Political Science and Law Press.

Ren, Y. (2016). State-owned enterprises adhere to the new theory of market-oriented reform. Guangzhou: Journal of Guangzhou University (social science edition).

Sun, X. Z. (2004). The Civil Law General Remarks. Beijing: Social Sciences Academic Press.

Wang, L. M. (2008). The Civil Law. Beijing: China Renmin University Company.

Wang, Y. (2013). On the Basic Principles of Civil Law and Their Relations. Hangzhou: Journal of Hangzhou Normal University (social science edition).

Xu, G. D. (2004). Interpretation of Basic Principles of Civil Law. Beijing: China University of Political Science and Law Press.

Xu, G. D. (2015). Analysis of Equality Provisions in Three Draft General Principles of Civil Law - the Beginning and Possible Development of the Retreat from Equality. Guangzhou: Jinan Journal (philosophy and social sciences edition).

Zhang, W. X. (1989). Rules, Principles, Concepts - the Model of Law. Chongqing: Modern Jurisprudence.

Zheng, X. J. (2007). Research on Fundamental Rights. Beijing: China Democracy and Legal System Publishing House.

\section{Notes}

Note 1. CiYuan (revised edition), Commercial Press, 1st edition, 1988, p. 538. 
Note 2. Chinese Dictionary (volume 2), Chinese Dictionary Press, 1st edition, 1988, p. 938.

Note 3. 2016 Wan 1502 Zhi No.1333

Note 4. 2007 Ha Min 1 Zai Zhong Zi No.68

Note 5. 2008 Zu Fa Min Chu Zi No.358

Note 6. 2017 Zhe 09 Min Zhong No.594

Note 7. 2012 Lian Min 2 Chu Zi No.00577

Note 8. 2016 Su 0891 Min Chu No.4597

\section{Copyrights}

Copyright for this article is retained by the author(s), with first publication rights granted to the journal.

This is an open-access article distributed under the terms and conditions of the Creative Commons Attribution license (http://creativecommons.org/licenses/by/4.0/). 